\title{
Sciendo
}

Research Article

\section{The Relationship between Public Debt and Economic Growth in Albania and Other Countries}

\author{
Eneida Përmeti Çifligu \\ PhD candidate at University of Tirana, \\ Faculty of Economy, \\ Department of Statistics and Applied Informatics, \\ Tirana, Albania
}

Doi: 10.2478/ajis-2018-0061

\begin{abstract}
The purpose of this study is the relationship between public debt and economic growth in Albania in post-dictatorships. Many authors have analyzed the mutual link between economic growth and public debt and the results and the methodologies are different in different countries and periods. Let's see what data are specifically about these two indicators (provided by the Ministry of Finance, the Bank of Albania and the International Monetary Fund). Does the public debt performance affects the trend of the economic growth or not? I have mentioned what are the main events and phenomena in Albania, in Europe and in the World that have affected the Albanian economy. For these years, I have made comparisons with situations in other countries.
\end{abstract}

Keywords: public debt, economic growth, deficit, Albania, other countries

\section{Introduction}

In this paper, I chose to address this topic, taking the cause of the European debt crisis, where the level of borrowing reached high levels in both developed and emerging economies. Although Albania managed to maintain a positive economic growth, its state debt remains high and worrying for scholars and economists. A high short term debt in our country means high risk of fiscal financing and in the medium term that growth may lower private sector lending and economic growth itself.

Sustainable economic growth is very important for every economy (as it is the growth of production, production capacities and all other components of an economy) and of course for Albania, which as a developing country aims to make progress to realize membership in the European Union.

On the other hand, it is equally important the public debt, the indirect government debt towards taxpayers. It can affect the monetary policy, the international level of credibility, the political process, the outflows of capital and the replacement of assets, so it has an effect on economic, social, political and international relations.

It is important to see what were the situations, political events and various external factors that have affected public debt and economic growth. We will analyze which are the most effective ways to be followed, in order to reduce the public debt burden.

\section{Review of Empirical Literature}

Many authors have studied the relationship between economic growth and public debt. The results are different. 
For example, Patillo, Poirson and Ricci (2002) have analyzed the data of 93 developing countries. The period of the study was from 1969 to 1998 . They built a model with panel data with fixed effects. The conclusion was that the external debt has a negative impact on economic growth for debt/GDP over $35-40 \%$.

Alfredo Schclarek (2004) have taken in consideration for his study 59 developing countries and 24 industrial countries during the years 1970-2002. He found a linear negative effect of the external debt on growth. Methodologically, the paper uses the GMM estimator, called dynamic system GMM panel estimator.

Kumar and Woo (2010), have done a study for the role of the public debt to the economic growth in long term. They have studied this issue in 38 developing and developed countries for the years 1970-2010. The result was a non-linear relationship between negative initial level of government debt and economic growth, but visible on $90 \%$ of public debt value. The increase of public debt affects the investment decrease and the decrease of capital stock growth per employee. Than affects the decrease of labor productivity. In industrial countries, an increase of $10 \%$ points in the debt to GDP lead to a $0.4 \%$ point decrease in investment (as \% of GDP). In developing countries an increase of $10 \%$ points in the debt lead to a $0.2 \%$ point decrease in economic growth. In developed countries the effect is smaller.

Patrizio Laina' (2011) studied the relationship between these two time series in the United States for the period 1959-2010. Firstly the author based his analysis on a time series regression and then builds his SVAR model. Then, the study continues with the Granger causality tests, the impulse response functions and the forecast error variance decompositions. According to these analysis the effect of government debt is positive in the short term and negative in the long term.

Abbas and Christensen (2007) had explored the role of domestic debt on economic growth in 93 countries, for the years 1975-2004. They used three methods: fixed effects, OLS and GMM and the results showed that the domestic debt had an important role in supporting economic development of developing countries.

Sheikh et al. (2010) analyzed the impact of domestic debt on economic growth in Pakistan for the years 1972-2009. They used the OLS method for their study. The result showed that the stock of domestic debt affects positively the economic growth in Pakistan.

Uzun et al. (2012) studied the relationship between debt and economic growth in transition countries for the period 1991-2009, using the autoregressive model with distributed delay (ARDL). The results showed a positive relationship in long term and these countries were positive in the Laffer curve.

Arcand, Berges and Panizza (2011) have analyzed the threshold above which financial development hasn't a positive effect on economic growth, in 44 advanced and emerging market economies for the period 1976-2005. An important conclusion is that the debt has a negative impact on output growth when the private sector debt reaches 104 to 110 percent of GDP. The effects are bigger for loans over $160 \%$ of GDP.

Balassoni, Francese and Page (2011) analyzed the relationship between the two variables, distinguishing the effects of domestic and external debt over a long period of time (1861-2010) in Italy. They used endogenous growth model for analyzing the endogeneity and the heteroskedasticity. The result is a negative correlation that is a little weakner since 1985 . The biggest influence has been the external debt.

Cechetti, Mohanti and Zampolli (2011) studied separately government debt, corporate debt and household debt to define empirically debt threshold beyond which growth suffers. The study includes 18 OECD countries during 1980-2010. They used the correlations and the standard panel growth regressions. The result is: a public debt threshold of $85 \%$ and a corporate debt threshold of $90 \%$.

\section{The Albanian Economy Compared to Other Countries}

It is important to analyze how the situation in developing countries (similar to our country) or even developed countries is presented, what are the levels reached by debt in relation to GDP, its structure, key lenders, policies followed, etc. 
In most of the countries that have borrowed from countries in North America, Latin America, Europe and elsewhere, creditors are: the International Monetary Fund, the Inter-American Development Bank, the World Bank, other creditors foreign and the rest belong to the domestic debt of non-banking financial institutions, banks, individuals, etc.

Generally all Central and Eastern European countries are characterized by high levels of public debt. This has come as a result of the need to restructure the economy and promote development. Various countries issue different securities to finance their state debt although the strategy followed is almost the same.

Compared with other countries, Albania can't be called a country with high debt, but at the same time its payout power is not high. We mention places like Italy, Iceland or Portugal which have a high level of government debt relative to GDP, but their level of development and solvency make the state debt burden not feel like us.

In order to resolve the high-deficit situation, fiscal policy is used, as in the case of Greece, where government spending was reduced to face the debt crisis. But policies can't be equally valid in different countries and at different times.

With regard to the economic situation in the world in 2001 , we can talk about a sharp slowdown in the US economy (after the September 11 attack), an inability to restore the Japanese economy and a modest increase in the European economy. During 2002 the world economy experienced a low growth. The beginning of 2002 gave positive signals which gradually faded with the outbreak of financial scandals in the US. This development was added to the unfavorable economic situation, causing stock markets to weaken constantly and leading to a US dollar devaluation. Under these conditions, funding for emerging markets came down.

The world economy was characterized by a moderate growth during 2003 . The uncertainties caused by the war in Iraq, the negative consequences that unrealistically raised prices in the US capital markets caused industrial production and international trade to suffer during April-June period. The Eurozone economy ran slower than anticipated in 2003.

The World economic activity had a higher growth rate during 2004 compared to the previous three years. The fiscal policy of many euro area countries has been an expansionist nature, which is a continuing concern, as a considerable number of member states have had a budget deficit over Maastricht criteria. Public finances during 2004 in the euro area countries continued to deteriorate. Economic expansion continued to be present in the US during 2004.

The Albanian economy grew by 6.0 percent in real terms, maintaining the average growth rate of the last five years. Albania's GDP growth during this period has been higher than the economic growth in other SEE countries, or that of newly-emerged EU countries.

According to IMF estimates, the world economy grew by 5.1 percent in 2006 . The economic growth for the period 2004-2006 has been the highest since the early 1970s. After a long period of stalemate, the economic activity in the Eurozone gained a new pace during 2006. In the US, the main reason for the slowdown of economic activity is related to the negative developments in the housing market, which have also had an impact on the sector of construction. In our country, based on available economic indicators, the economic growth rate is estimated at about 6 percent. This growth is accompanied by price stability, expressed in annual average inflation of 2.4 percent.

The world economy in 2008 was characterized by a slowdown in growth rates, marking 3.4 percent, after a four-year period with an average growth of 5 percent. This slowdown came mainly as a result of the financial crisis that began in the US in 2007 and widened in mid-2008, increasing geographical coverage in developed European countries and later in Central and Eastern Europe. The euro area economy has experienced slowed growth rates in 2008, accounting for about 0.9 percent, compared to 2.7 percent in 2007. After a long period of satisfactory GDP growth, the United States has been characterized by a deterioration of the economic activity during 2008 . The persistent depreciation of financial instruments at stock markets, the deterioration of the balance of major financial firms and the accelerated fall in house prices directly impacted the performance of the real economy.

The performance of the Albanian economy has generally been characterized by positive features during 2008.

2009 was characterized by a contraction of world economic activity as a result of the 
economic downturn of developed countries and the sluggish economic slowdown of developing countries. This performance of the economy marked the first negative value over a period of 20 years. The euro area economy has shrunk considerably during 2009. In the US, GDP for 2009 was $2.4 \%$ lower compared to 2008.

In Greece, the economy deteriorated during the second half. In this country, the decline in GDP combined with macroeconomic structural problems contributed to the deepening of the budget deficit to four times higher than the limits laid down in the Maastricht Treaty and in the fall of 2009 the Greek economic crisis began.

After a year of economic contraction, the World economic activity returned to positive growth rates in 2010 . After a deep contraction of the economy during 2009, the US economy, influenced by the continuation of fiscal and monetary stimulus, showed upward trend over this year.

The World economy marked a slowdown in growth rates during 2011. The deepening of the debt crisis and the spreading to many of the developed countries has negatively impacted the economic performance of these countries. The tensions associated with this factor have been transmitted to the financial markets, making capital exchanges more difficult and the required higher risk premiums. Developing countries have recorded faster growth than developed countries, albeit with moderate values from the previous year. The economic downturn of the industrialized countries has conditioned the overall performance of the world economy, affecting the external demand of developing countries, where exports constitute a major item in GDP growth.

The public debt crisis, present in many Eurozone countries, negatively affected the dynamics of many sectors of its economy during the 2012, too. The world economy continued to slow down in 2012. Many of the developed countries experienced shrinkage of GDP during this year, while developing economies marked a moderation of growth rates. The euro area economy has experienced a contraction of GDP during 2012. The US economy has recorded positive growth rates during 2012.

Macroeconomic developments in the country were significantly affected by the slowdown in global economic growth, from the cost shocks that increased the import bill and from the sluggish domestic demand. However, in general, although negatively impacted by the global, European or regional aggravated situation, our country has recorded positive economic growth and has successfully cope with this crisis situation.

\section{Data on Economic Growth and Public Debt}

Let's look at what values have been recorded over the years for growth and public debt, linking the political events and changes in the country and analyzing the relationship between the two indicators.

Between 1993 and 1996, the average annual growth amounted to 9.2 percent after a decline in 1990-1992, while the pyramid scheme crisis in 1997 triggered an economic downturn of 11 percent. However, the economy recovered rapidly and the real GDP growth rate for 1998 reached 8.8 percent and in 1999, 12.9 percent. During this period, in the equilibrium of the economy, a key role played the Fiscal Policy.

In 1995, we had a budget deficit of 7.8 percent of GDP, which was financed with 66.5 percent with Treasury Bills and the rest of 33.5 percent with direct loans from the Bank of Albania and foreign financing. Massive privatization, undertaken during 1995, would have led to the negative effects of liberalization of prices and wages, production requirements, and external competition being reduced and as a result the country spent a sustained period in increasing inflation.

During 1995, the main achievements were the sustainability of the growth rates of production, regardless of the inherited structural problems we have had (it is estimated that the growth of gross domestic product during 1995 is 13.4 percent, compared with 7.4 percent in 1994 ); the inflation at an acceptable annual rate of 6 per cent; the increase of available currency reserves; the stability of the national currency; the mass privatization and the reduction of the regulatory role of the state in economy; the improving of the level of employment; the unblocking of foreign capital inflows as a result of external debt settlement etc. After a long recession, in 1995 the economic cycle began, typical of an economy that was moving towards that of the market. An important aspect of macroeconomic developments is the growth of investments. During 1991-1994, domestic 
investment doubled. This pace continued during 1995. The largest investments during this period were directed to infrastructure, construction, etc.

During the period 1993-1995, a series of structural decisions and adjustments were undertaken, the fruit of which was overall macroeconomic stability. The ambitious program of economic reforms, the transformation of our economy into a market economy through a broad privatization policy of state and land enterprises, the large liberalization of consumer prices, the liberalization of foreign trade, the banking system reform, the reform in the legislative system, the expansion and improvement of the country's fiscal system, the restructuring of state-owned enterprises, the significant inflows in the form of economic assistance and capital inflows abroad, the remittances by a large number of Albanians working overseas etc. are decisive factors in achieving this stability. Since the beginning of the stabilization program in '93, the total production has grown remarkably. Albania recorded the highest cumulative GDP growth among all transition countries following the economic collapse that these countries experienced in the early 1990s. The overall GDP (GDP) during 1996 (with constant 1990 prices) is estimated to have risen to 8.9 percent.

This year, Albania faced the flourishing of pyramid schemes. It is said that in these schemes were invested considerable amounts which converted into USD are usually estimated to be about USD 1.5 billion. Revenues in the form of interest these lenders paid to lenders led entirely to consumption, affecting significantly the level of national savings. The activity of these firms had many negative side, not only in the social view, fueling inactivity but also economic, curbing investment in the economy, and destroying financial savings. While in the banking system, it further aggravated the situation of banks not only as a result of the fall in deposit growth rates, and in a few months and their decline, but also in the turmoil of public confidence that is so much needed for them. On the other hand, this activity made it very difficult for the Bank of Albania to control the monetary situation, allowing large flows of money outside the banking channels. The investment activity of these firms was almost negligible, which almost completely paralyzed the economy, reducing its production activity.

The general crisis that included the country in 1997 is widely reflected in all economic and financial indicators. Inflation rose very rapidly in the first half of 1997, and the collapse in public order turmoil led to a sharp decline in ALL confidence, a large drop in output and the creation of larger reserves to cope with unexpected situations and speculations. The ALL's value dropped to 40 percent against the major international and regional currencies. Beyond the incalculable damage from the bankruptcy of the pyramid companies, the Albanian economy faced a mass phenomenon of destruction and plunder and total destruction of public order. Before this phase of destruction could not resist the few Albanian or foreign productive capacities. State finances became inexistent and the only source of financing of the budget deficit was Bank of Albania's credit. The crisis of the Albanian economy at the end of 1996 and the beginning of ' 97 was followed by the bankruptcy of firms in the informal market. The infinite flourishing of the informal market was favored by a number of factors, such as the economic environment of 1995-96, the legal deficiencies, the lack of a formal consolidated market and its institutions in the country, the lack of culture economics by the general public etc.

In 1998, the economic situation in our country would be affected by the situation in the Balkan region, where the biggest problem was the situation in Kosovo; the deepening and spread of the economic crisis in many developed and developing countries; realization of the unique monetary policy in the countries that created the Eurozone, finalized with the introduction of the euro.

During 1998, macroeconomic balances were restored, a fast economic growth of 8 percent per year was ensured, while inflation fell to 8.7 percent from 42 percent at the end of 1997. Balancing of equilibriums was enabled, to a large extent, from the implementation of a tight monetary and fiscal policy as well as the strengthening and improvement of the legal basis. Since 1993, excluding 1997, the Albanian economy has consistently experienced high growth rates. After a total downturn in the first years of transition, the country's economic growth recorded a high level of 10 percent in 1993. Over the next few years, the economy maintained this performance, accelerating the pace, something more in 1995 and 1996, to completely stop the overthrow of the pyramids.

The statistics of the Government accounts, at the end of 1999, reflected a more optimistic situation and noted a reduction in the budget deficit financed by domestic sources. 
The economic growth stabilized during 2001-2002, with an average rate of 6.5 percent. Meanwhile, starting from 2000 to 2008, the annual average growth was 6 percent. After a 7.5 percent annual growth rate in 2008, economic growth slowed down, recording only 3.4 percent in 2009 .

The economic activity during 2007 is estimated to have increased by about 6 percent. All of the country's economic activity has developed under the conditions of a controlled inflation environment, despite the difficulties caused by developments in the global economy. 2007 and the first months of 2008, coincide with a relatively complex situation with regard to global developments. Currently, we face a sharp increase in raw material prices and food products. The financial markets reflected the negative effects of the credit crisis that the US economy generated. Central banks have injected liquidity steadily, while the Federal Reserve has aggressively lowered the key interest rate, in order to avoid a downturn in the economy. These developments have given their impact on our economy, mainly on the performance of consumer prices. The 2007, has been characterized by a large movement in the capital account, both in incoming and outgoing flows. The most prominent development coincides with foreign direct investments in the economy. The privatization of Albtelecom, the increase of foreign capital participation in the ownership of the financial sector, have played the main role in this growth. The economic growth for 2007 is estimated to have reached 6.0 percent.

The country's economic activity and the development of Albanian financial markets developed under the influence of the global economic and financial crisis. The Albanian economy showed an admirable degree of resistance during 2009. Although the consequences of the global crisis were felt early in the economic activity, as in most of the countries in the region and in the developing ones, the sound initial state of the economy and our financial system, as well as the rapid and decisive response of the monetary and fiscal authorities, managed to limit their impact on our economy. The Albanian economy managed to provide a positive growth during the year, maintaining the most essential macroeconomic balances and the financial system stability.

2010 can be considered a positive year for the Albanian economy. Although there was a strong shock from the external environment, the Albanian economy managed to record economic growth, consolidate macroeconomic stability and strengthen the financial system during 2010 . The economic activity grew progressively during this year, also helped by the positive performance of the economy world economy and the dynamism of the private sector.

During the year 2011, macroeconomic developments in the country were significantly affected by the slowdown in world economic growth, reflecting the impact of the crisis. The official Bo A data show that economic growth in 2012 and 2013 remained at positive levels, but it slowed down compared to the rhythms recorded a year earlier. In 2014 and onwards the registered values have been increasing.

The economic and financial shocks, both internal and external, have affected the slowdown of economic growth but did not affect the country's macroeconomic and financial stability during 2012. The budget deficit was estimated at $3.4 \%$ of GDP, while public debt is estimated to have reached $61 \%$ of GDP at the end of the year.

2013 was a challenging year for the economy and Albanian financial markets. The Albanian economy showed strong signs of slowdown during 2013.

In June 2014, Albania was granted candidate status for membership in the European Union. The Albanian economy continued to operate with incomplete capacity and faced an unfavorable external environment. The world economy marked a positive growth rate in 2014. Despite the positive developments, markets and the world economy remain surrounded by uncertainty elements, linked to geopolitical tensions in some regions as well as to the effects of the ongoing crisis that are still present. The Albanian economy marked an improved economic activity in 2014.

The Albanian economy marked an improvement during 2015, too. The pace of economic growth accelerated, while the main indicators of economic and financial health generally had an upward trend. Although growing, economic activity in the country remains below its potential level. The economic growth of 2015 was higher than last year. The public debt amounted to about $72.2 \%$ of GDP at the end of 2015, an increase of about 0.4 percentage points compared to the previous year.

Regarding the government debt performance, we can say that during the period 1992-1995, there is a downward trend. As reflected by the chart, there is a fall in the budget deficit. Relationship 
with economic growth is negative for this period.

During 1995-1996 the level of public debt grew as a result of the growth of the deficit. From 8.5 percent in 1995, the budget deficit reached 11.2 percent in 1996.

During the period 1996-2002 we noticed a volatility of public debt, due to the instability of the budget deficit and external debt as well as the increase of domestic debt.

From 2002 to 2016 the trend has been more stable.

According to the IMF data on real economic growth in Albania, the lowest value was achieved in $1997(-10.9 \%)$, and the highest in $1999(12.9 \%)$ are also reflected in graph 1)

According to the Ministry of Finance and Economy data on debt indicators, its highest value was in 1997 (84.6\% of GDP) and the lowest in 2007 (53.5\% 3 GDP) (Graph 2)

Based on the above analysis we can say that the reduction of economic growth coincides with the periods when the debt has been increasing and vice versa.

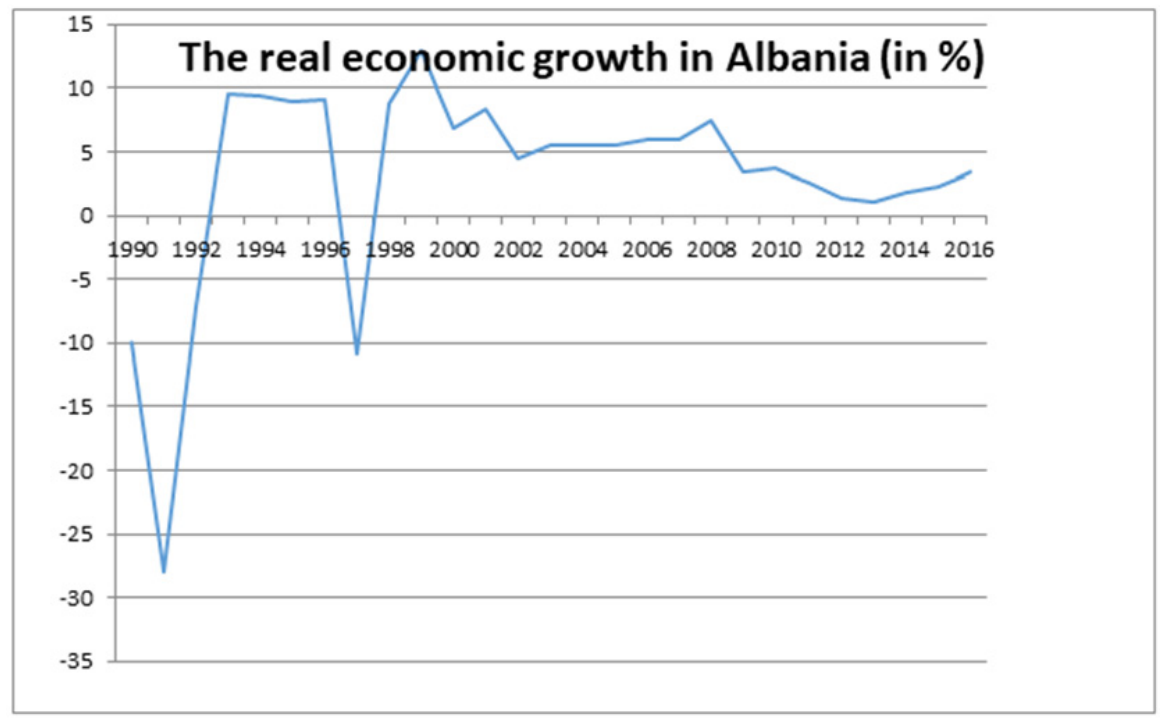

Graphic 1: IMF data (elaborated by the author)

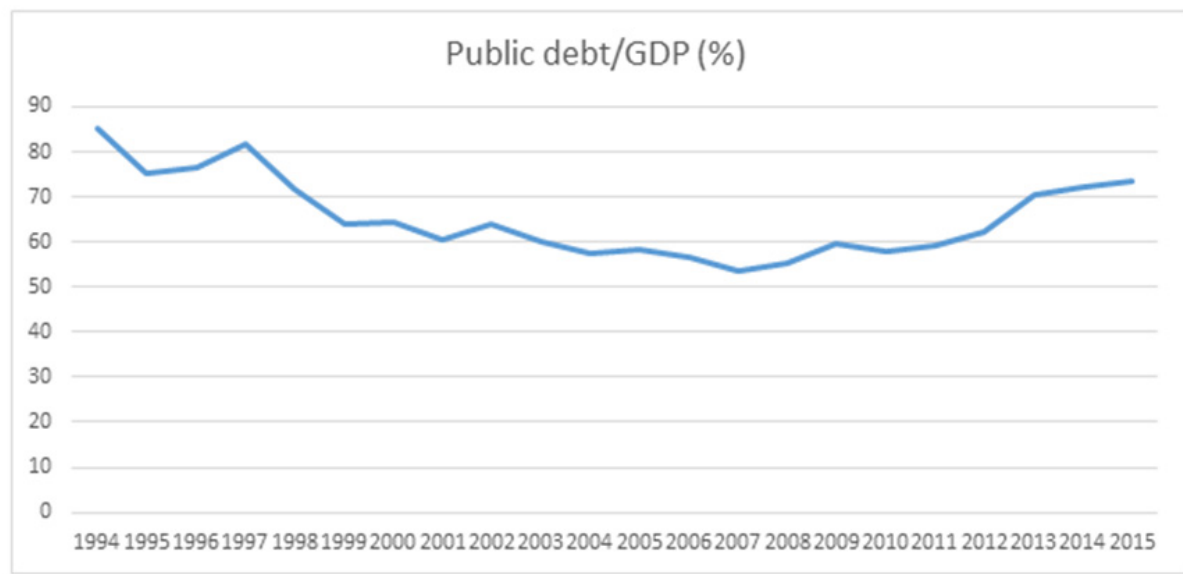

Graphic 2: IMF data (elaborated by the author) 


\section{Conclusions}

The role of public debt on economic growth is quite a topic important, which should be taken into account by policymakers in Albania.

The main factors that have contributed positively to the economic growth in Albania over these years are: shifting the workforce from low productivity to high productivity, prudent fiscal and monetary policies, sustainability of the macroeconomic situation, and steady growth of investment.

The main factors that have led to public debt growth are the growth of the deficit and the increase in public investment.

The external debt has risen faster than the domestic one since 2007, and this is a concern for financial stability in the country, because such a composite state debt carries a higher exposure to changes in world financial markets and the exchange rate.

The budget deficit was one of the main causes that affected directly the growth of public debt, while it was fully funded by the latter. Policy makers should not choose to reduce government spending as their best option to reduce the budget deficit, but they should choose to raise tax revenues. The best way to do this is to apply controls and inclusive sanctions to anyone who avoids paying taxes. Also the use of tax money should be made transparent to the general public, because transparency enhances confidence, and the latter will increase the awareness of taxpayers that their money is being used for their benefit.

\section{References}

Abbas, S and Christensen, E (2007): The Role of Domestic Debt Markets in Economic Growth: An Empirical Investigation for Low-income Countries and Emerging Markets, IMF Working Paper, page 20-23

Ahlborn M. and Schweickert R. Public debt and economic growth-economic system matter, Berlin:Springer

Arcand. J.L, Berkes. E and Panizza. U, "Too Much Finance," mimeograph, UNCTAD, March 2011

Balassone. F, Francese. M and Pace. A, "Public Debt and Growth in Italy," Quaderni di Storia Economica, Banca D' Italia No. 11, October 2011

Bank of Albania, Annual report, 1995

Bank of Albania, Annual report, 1996

Bank of Albania, Annual report, 1997

Bank of Albania, Annual report, 2005

Bank of Albania, Annual report, 2006

Bank of Albania, Annual report, 2008

Bank of Albania, Annual report, 2015 [Online] Available: https://www.bankofalbania.org

Cecchetti S., M S Mohanty and Zampolli F. "The Real Effects of Debt", forthcoming in Achieving Maximum Long-Run Growth symposium sponsored by the Federal Reserve Bank of Kansas City, Jackson Hole, Wyoming, 25-27 August 2011

IMF Data, [Online] Available: http://www.imf.org/external/datamapper/ngdp_rpch@weo/oemdc/advec/weoworld/alb

Greiner A. and Fincke. B. Public debt, sustainability and economic growth, Theory and Empirics, Switzerland: Springer

Greiner A. and Fincke. B. Public debt and economic growth, Berlin: Springer

Ministry of Finance and Economy, Indicators of Debt, [Online] Available: http://www.financa.gov.al/al/raportime /borxhi/treguesit-e-borxhit

Kumar. M and Woo. J (2010). "Public Debt and Growth," IMF Working Paper WP/10/174 (July)

Lainà P. (2011): "Dynamic Effects of Total Debt and GDP: A Time-Series Analysis of the United States", Master Thesis, Aalto University School of Economics, page 74-77

Pattillo C., Poirson. H and Ricci. L, 2002, "External Debt and Growth," Review of Economics and Institutions, Fall 2011, vol. 2, issue 3, Article 2

Schclarek. A "Debt and Economic Growth in Developing and Industrial Countries" T December 15, 2004. Available: http://project.nek.lu.se/publications/workpap/Papers/WP05_34.pdf

Sheikh. M. et al. (2010): "Domestic Debt and Economic Growth in Pakistan: An Empirical Analysis", Pakistan Journal of Social Sciences (PJSS), Vol. 30, Nr.2 (December 2010), page. 373-387

Uzun. A et al. (2012): "The Impacts of External Debt on Economic Growth in Transition Economies", Chinese Business Review, ISSN 1537-1506, May 2012, Vol. 11, Nr. 5, page 491- 99 